\title{
Reconciling Immigration and Agricultural Labor Concerns for a Sustainable State Economy ${ }^{1}$
}

\author{
Chandra Bowden, Alexa Lamm, Hannah Carter, Tracy Irani, and Sebastian Galindo²
}

\section{Introduction}

The following EDIS publication is a brief description of recent discussions and policies surrounding immigration and agricultural labor issues in Florida. The goal of this publication is to provide brief but clear information about the trends in policies that can be used by Extension agents to increase educated conversations around immigration issues. Immigration in Florida is a contested issue, and the public may call upon Extension agents as a source of unbiased information. Having an understanding of this issue can help facilitate communication.

The Florida agricultural industry requires a continuous, economically feasible, and authorized workforce in order to sustain the state's economic growth. Historically, unauthorized workers have comprised the majority of U.S. agricultural laborers (González, 2012; National Center for Farmworker Health, Inc., n.d.). There is a national agenda to increase the number of lawful laborers in order to protect national security and to ensure the development of viable communities. Employers today face increased scrutiny of their hiring practices to ensure national immigration policies are upheld. Employers of the agricultural industry and policymakers must work cooperatively when addressing immigration issues in order to maximize profitability for agricultural producers and promote sustainable communities with a viable workforce.
This publication 1) describes the Immigration Reform and Control Act (IRCA) of 1986, 2) explains the use of E-Verify as a means to satisfy the requirements of IRCA, 3) presents the views on immigration held by Florida agricultural and natural resource opinion leaders, and 4) provides recommendations for opinion leaders in order to support the reconciliation of immigration compliance and labor needs of Florida's agricultural sector.

\section{Immigration Reform and Control Act}

\section{Components of IRCA}

The Immigration Reform and Control Act (IRCA) of 1986 is a federal policy requiring all employers to hire only persons who are legally entitled to work in the United States. IRCA

- makes it unlawful for an employer to knowingly hire, recruit, or refer for a fee an alien unauthorized to work in the United States who has not completed an employment authorization form (I-9 form);

- prohibits employers from continuing to employ aliens unauthorized to work in the United States once they learn of their employment status;

1. This document is WC132, one of a series of the Agricultural Education and Communication Department, Florida Cooperative Extension Service, Institute of Food and Agricultural Sciences, University of Florida. Original publication date December 2012. Visit the EDIS website at http://edis.ifas.ufl. edu.

2. Chandra Bowden, Ph.D. student; Alexa Lamm, assistant professor and director, National Public Policy Evaluation Center; Hannah Carter, assistant professor and director, Wedgworth Leadership Institute; Tracy Irani, professor and director, Center for Public Issues and Education; and Sebastian Galindo, assistant professor, Agricultural Education and Communication Department, University of Florida, Institute of Food and Agricultural Sciences, Gainesville, FL 32611. 
- requires employers to keep records of employee identification and employment eligibility;

- expands employer liability for hiring undocumented aliens if it can be proven the employer should have known an employee was unauthorized to work in the United States; and

- prohibits discrimination against individuals based on national origin or citizenship status (Roka, Olexa, Smallwood, Polopolus, \& Fountain, 2009).

\section{Employer Requirements Under IRCA}

To be in compliance with IRCA, employers must

- have their employees complete their part of the I-9 form when they begin work and check the I-9 form for completeness;

- complete their part of the I-9 form within 3 days of workers' employment or at the start of hire if employment is less than 3 days;

- inspect employee documents that establish identity and work eligibility;

- retain the I-9 form for at least 3 years, or 1 year after an employee leaves, whichever is longer; and

- present the I-9 form for inspection when requested by U.S. Citizenship and Immigration Services, U.S. Department of Labor, or U.S. Office of Special Council officers (Roka et al., 2009).

\section{E-Verify}

\section{The Creation of E-Verify}

In 1996, Congress passed the Illegal Immigration Reform and Immigrant Responsibility Act (IIRIRA). IIRIRA required the Social Security Administration and the U.S. Citizenship and Immigration Services to initiate an employment verification pilot program. As a result, the pilot program, E-Verify, was created. E-Verify is an Internet-based program that allows employers to carry out the legal requirements of IIRIRA by verifying the employment eligibility of all new employees (U.S. Citizenship and Immigration Services, 2011).

Through E-Verify, employers are able to compare electronically employee information on the I-9 form with Social Security Administration and Department of Homeland Security records to verify the identity and employment eligibility of new hires (U.S. Citizenship and Immigration Services, 2011). E-Verify also has a photo-matching tool that allows employers to view green card, employment authorization, or passport photos in order to verify applicant identity (Smith, 2011).

\section{Advantages of E-Verify}

E-Verify is a free program and is available in all 50 states, the District of Columbia, Puerto Rico, Guam, and the U.S. Virgin Islands (U.S. Citizenship and Immigration Services, 2011). Because E-Verify is an Internet-based verification program, it is assumed to be more reliable than the paperbased I-9 form, where document authenticity is at the discretion of the employer (Smith, 2011). Advocates of the E-Verify program state that verification of a legal employee is fast and $99.5 \%$ accurate (Smith, 2011).

\section{Disadvantages of E-Verify}

The E-Verify database has been considered by some to be incomplete and, therefore, inaccurate (Silver, 2012). Additionally, using E-Verify is said to be time consuming because employers can only check one employee at a time (U.S. Citizenship and Immigration Services, 2011). The time it takes to verify employees can be especially problematic when agricultural producers are hiring hundreds of seasonal workers prior to harvest. Employers must also use the program to verify seasonal nonimmigrant workers who already are approved through the $\mathrm{H}-2 \mathrm{~A}$ program (Redmon, 2011). The redundancy of verification can be time consuming.

\section{E-Verify Use in Florida}

Currently, E-Verify is a voluntary program for most employers. In 2011, Florida Governor Rick Scott signed an executive order that required new hires of state agencies and state contractors to be cleared through the E-Verify database (Klas, 2012). The governor was unable to convince the state legislature to pass a law that would require Florida businesses to use also the database when verifying new hire identification and work eligibility (Klas, 2012).

\section{The Costs of E-Verify for Florida Agricultural Businesses}

Leaders within the Florida agricultural and natural resources (ANR) industry recognize the need for Florida businesses to have a continuous, economically feasible, and authorized workforce. The physically demanding nature of crop production and harvest makes the work less appealing to many native U.S. citizens. Consequently, most laborers in 
these businesses are non-native seasonal or migrant workers, guest workers, or illegal immigrants.

With U.S. unemployment in 2012 above 8\% (roughly 23 million Americans are unemployed) (Smith, 2012) and 7 million individuals working illegally in the United States (Smith, 2011), there has been a push in several states, including Florida, to verify electronically employment eligibility.

Technically, the E-Verify program is free. A University of Florida study demonstrated that increasing compliance costs with government regulations (e.g., immigration compliance, training courses, etc.) constituted a "phantom cost" to Florida producers (Muraro, Roka, Spreen, \& Timpner, 2007). The study showed that the cost of completing time-consuming administrative tasks reduced producer working hours for crop cultivation and increased overhead costs (e.g., clerical hires). A study of Florida citrus growers revealed clerical employees spend an estimated 81.5 annual hours on immigration compliance activities. Managers and laborers spend 16.5 and 8.5 annual hours, respectively, on immigration compliance tasks. In total, more than 2.540 -hour work weeks are dedicated to this one administrative duty (Muraro et al., 2007). Florida producers are under pressure to produce high-quality commodities at prices that are comparable to agricultural products in other countries that do not have the same "phantom" compliance costs. This puts Florida farmers at a disadvantage to foreign competitors (Muraro et al., 2007).

How do agriculturally supported states, such as Florida, reconcile the dilemma of following federal immigration policy while simultaneously meeting its labor needs? Let's take a look at an immigration compliance case study in the state of Georgia.

\section{Lessons Learned From Georgia Statewide E-Verify Legislation}

In May 2011, Georgia Governor Nathan Deal signed House Bill 87 requiring statewide E-Verify usage for businesses with employees who worked 35 or more hours a week. Implementation of the legislation began January 1, 2012, for employers with 500 or more employees; July 1, 2012, for employers with 100-499 employees; and begins July 1, 2013, for employers with 10-99 employees (Georgia Fruit and Vegetable Growers Association, 2011a).

Although the law was not to be implemented until 2012, the legislation's impact was immediate (Conan, 2012). Many laborers chose to work in neighboring states for fear of being targeted by law enforcement officials for immigration violations (Schneider, 2011). In 2011, the University of Georgia Center for Agribusiness and Economic Development conducted a survey of Georgia farmers. The respondents represented over $46 \%$ of acreage available for harvest in spring 2011. These farmers reported a $46.4 \%$ reduction in labor. Growers had only 7,686 laborers when, in a normal year, 12,930 laborers are needed (Georgia Fruit and Vegetable Growers Association, 2011b). In response to the labor shortage, the state held agricultural job fairs and recruited U.S. citizens serving probation (Ryssdal, 2011). The financial losses that were directly attributed to harvest or packing shortages were approximately $\$ 140$ million. Economic impact was not limited to labor shortages. The estimated total economic impact across the state in 2011 was \$391 million. Researchers estimate that a total of 3,260 non-harvesting jobs across the state were lost (Georgia Fruit and Vegetable Growers Association, 2011b).

Among the survey respondents, 53\% of vegetable growers said they would decrease acreage of vegetable crops for 2012. Sixty-five percent of berry growers said they would maintain the same acreage of berry plants for 2012, which is likely because of the relatively high investment costs of these crops. Many berry growers, however, said they would mechanically harvest more acres than in the past. Mechanical harvesting results in greater berry damage during harvest. Consequently, these farmers likely will forfeit the more lucrative fresh berry markets for frozen and processed berry markets (Georgia Fruit and Vegetable Growers Association, 2011b).

In addition to economic losses, the state of Georgia has had difficulty enforcing E-Verify participation by businesses and state agencies (Silver, 2012). Despite the legislation, not all employers have signed up for the program. Additionally, the state does not have a budget to fund audits of employers to determine compliance (Redmon, 2011).

Leaders within the Florida ANR industry, including the Florida Fruit and Vegetable Association, predict a similar fate for Florida businesses if the state does not generate adequately a viable agricultural labor force while ensuring immigration reform compliance (Florida Fruit and Vegetable Association, 2012). Thus, it is important to understand what policymakers need to know about immigration and labor issues, and what ANR industry leaders perceive as the impacts of E-Verify. 


\section{Research Study}

\section{Florida ANR Opinion Leaders' Perceptions of Immigration Issues in Florida}

A study conducted in fall 2011 examined how opinion leaders within the Florida ANR industry felt about how E-Verify information was distributed, what they felt policymakers needed to know about the issue, and the impacts they felt would occur as a result of statewide implementation of E-Verify. Opinion leaders in ANR were specifically targeted for this study because they represent diverse, industry backgrounds, including specializations in horticulture, citrus, cattle, vegetable production, and related agricultural and natural resource industry roles.

The 30 participants involved in the University of Florida/ Institute of Food and Agriculture Sciences leadership program and the Wedgworth Leadership Institute for Agriculture and Natural Resources (WLIANR) class VIII were surveyed. WLIANR participants were selected as the target audience based on their opinion leadership role, nominations from industry, and geographic representation across the state of Florida. The participants are considered leaders within the industry. Of the 30 participants for this study, $60 \%$ were male and $40 \%$ were female, ranging in age from 27 to 55 . Twenty-seven of the participants were white, two were Hispanic, and one was Asian. During the summer of 2011, an online survey was administered asking specific questions about the issue of immigration. All 30 participants responded.

\section{Results}

When asked, "Where do you get information from regarding immigration and labor issues?" respondents indicated that general media (i.e., magazines, newspapers, general news, TV) were the most common sources of information. Information from professionals (i.e., lawyers, border control) and agricultural associations and publications (i.e., Florida Nursery Growers and Landscape Association, Florida Fruit \& Vegetable Association, and agricultural publications) was the second-most common source of information. The Internet, business contacts, and personal experience were the least common sources of information for respondents.

When asked, "What do policymakers need to know regarding immigration and labor issues?" respondents emphasized the "critical" importance of migrant workers to the sustainability of Florida agriculture, and that the presence of a reliable labor supply was essential to sustaining the industry of Florida agriculture. Respondents would like to see an attractive guest worker program that is workable, affordable, enforceable, and expedites the clearance of immigration workers.

When asked, "What outcomes do you predict relating to labor/immigration issues?" the respondents had varying views. Several were unsure what to predict about the future. A few discussed the development of a guest worker program. Other respondents predicted outcomes that would occur as a result of not reconciling immigration reform with labor needs. These included more unemployed American citizens, insufficient laborers for the harvesting and processing of crops, and an increase in the price of gross domestic products that will lower the value of the dollar, increase imports, and weaken the economy.

\section{Recommendations to Reconcile Immigration and Labor Needs for Florida}

WLIANR participants did not suggest the need for a statewide E-Verify program. Instead, participants stressed the need for an improved guest worker program, particularly the development of a program that is less complicated and less expensive than the $\mathrm{H}-2 \mathrm{~A}$ program.

The development of a new guest worker program will be expensive (Florida Fruit and Vegetable Association, 2012). The state would do well to leverage its resources with neighboring states to maximize the likelihood of success.

As public opinion leaders, the WLIANR participants should accurately and ethically communicate the views of the interest groups they represent. Contentious issues like E-Verify make it imperative that these public opinion leaders communicate with policymakers who may have different views than the ones these leaders represent. The WLIANR class VIII developed the following suggestions when communicating their views about the impact of immigration reform on the agricultural labor force.

WLIANR participants felt that communication with policymakers about labor and immigration reform should be personal and include stories, quantitative data, and possibly pictures. They thought that opinion leaders should draw policymakers' attention to recent media and third-party research with scientifically sound data on a proposed or finalized regulation that impacts the agricultural industry, as well as brief staff prior to the meeting.

The participants noted that points on labor and immigration reform that will have the most influence include: 
- Explaining how voters in the policymaker's district will be affected;

- Describing public good/social justice;

- Informing policymakers of the agriculture industry's impact on local economy and how that impact will be influenced; and

- Describing how regulations will impact public safety.

When working with policymakers who share the views represented by the opinion leaders, WLIANR participants suggested that opinion leaders should:

- Thank them for their support;

- Ask how the opinion leader can help support the policymaker on current/future issues; and

- Provide the policymaker with data to persuade others.

When working with policymakers who do not share the views represented by the opinion leaders, WLIANR participants suggested that opinion leaders should:

- Ask the policymaker if there is additional information they can provide to assist in decision-making;

- Build a relationship with the policymaker's staff in order to develop trust;

- Explain the percentage of the constituency impacted by the regulation;

- Separate emotions and facts; and

- Put the policymaker in contact with a policymaker who supports the issue.

When working with policymakers who are neutral to the views represented by the opinion leaders, WLIANR participants suggested that opinion leaders should:

- Put the policymaker in contact with a colleague who supports the issue;

- Invite the policymaker on a field tour;

- Ask the policymaker if the leader can provide additional information to assist in decision-making;
- Build a relationship with the policymaker's staff in order to develop trust; and

- Explain the percentage of the constituency impacted by the regulation.

This publication is part of a series to address the communication, evaluation, and leadership needs of stakeholders in Florida's agricultural and natural resource sectors developed by the UF/IFAS Center for Public Issues Education in Agriculture and Natural Resources, the UF/IFAS National Public Policy Evaluation Center for Agriculture and Natural Resources, and the Wedgworth Leadership Institute.

\section{References}

Conan, N. (Host). (2012, April 30). How new immigration laws are changing states. [Radio broadcast]. In Talk of the nation. Washington, DC: National Public Radio. Retrieved from http://www.npr.org/2012/04/30/151700266/ how-new-immigration-laws-are-changing-states

Florida Fruit and Vegetable Association. (2012). Harvester. Retrieved from http://harvester.ffva.com/labor-update/

Georgia Fruit and Vegetable Growers Association. (2011a). Notes on the immigration reform bill-H.B. 87-Passed by the general assembly on April 14, 2011. Retrieved from http://gfvga. org/2011/05/h-b-87-passed-by-the-general-assembly/

Georgia Fruit and Vegetable Growers Association. (2011b). Press statement- economic impact report 10-4-2011. Retrieved from http://gfvga.org/2011/10/ press-statement-economic-impact-report-10-4-2011/

González, E. (2012, March 6). Migrant farm workers: Our nation's invisible population. Retrieved from http://www.extension.org/pages/9960/ migrant-farm-workers:-our-nations-invisible-population

Klas, M. E. (2012, June 21). Rick Scott shifts on E-Verify promise. Tampa Bay Times. Retrieved from http://www.tampabay.com/news/politics/stateroundup/ rick-scott-shifts-on-e-verify-promise/1236401

Muraro, R., Roka, F., Spreen, T., \& Timpner, M. (2007). The "phantom costs" of Florida's citrus industry. FE699. Gainesville: University of Florida Institute of Food and Agricultural Sciences. Retrieved from http://edis.ifas.ufl. edu/fe669 
National Center for Farmworker Health, Inc. (n.d.). About

America's farmworkers: History. Retrieved from http://www. ncfh.org $/$ ?pid $=4$ \&page $=2$

Redmon, J. (2011, September 3). Georgia's new immigration law requirements confuse businesses. The Atlanta Journal-Constitution. Retrieved from http://www.ajc.com/ news/georgia-politics-elections/georgias-new-immigrationlaw-1157121.html

Roka, F., M. Olexa, K. Smallwood, L. Polopolus, \& C. Fountain. (2009). 2009 Handbook of employment regulation affecting Florida farm employers and workers: Immigration reform programs [federal.] FE402. Gainesville: University of Florida Institute of Food and Agricultural Sciences. http:// edis.ifas.ufl.edu/fe402

Ryssdal, K. (Host). (2011, June 16). Probationers could be allowed to work on farms in Georgia. [Radio broadcast]. In Marketplace. Los Angeles, CA: American Public Media. Retrieved from http://gfvga.org/2011/06/probationerscould-be-allowed-to-work-on-farms-in-georgia/

Schneider, C. (2011, June 3). Farm owners, workers worry about immigration law's impact on crops. The Atlanta Journal-Constitution. Retrieved from http://www.ajc.com/ news/farm-owners-workers-worry-966607.html

Silver, M. (2012, June 26). E-Verify not on people's minds in Georgia. The Epoch Times. Retrieved from http://www. theepochtimes.com/n2/united-states/e-verify-not-onpeoples-minds-in-georgia-256999.html

Smith, L. (2011, June 13). E-Verify works; let's use it. Los Angeles Times. Retrieved from http://www.latimes. $\mathrm{com} /$ news/opinion/commentary/la-oe-gallegly-everify-20110613,0,6234124.story

Smith, L. (2012, February 21). E-Verify will help Americans land the jobs they work hard for. FoxNews.com. Retrieved from http://www.foxnews.com/opinion/2012/02/21/everify-will-help-americans-land-jobs-deserve/

U. S. Citizenship and Immigration Services. (2011). E-verify user manual for employers. Retrieved from http://www. uscis.gov/USCIS/Verification/E-Verify/E-Verify_Na-

tive_Documents/manual-employer_comp.pdf 